\title{
Belgrade Street Drama of the 1990s: (Re)constructing History and Memory
}

\begin{abstract}
The analytical approach employed in this paper ${ }^{1}$ focuses on the chronological and symbolic field of (re)constructing the past - mass gatherings between 1988 and 2000 in Belgrade. I problematize mass and public events in Belgrade through chronologies of these events, their contents, the types of meetings and the politics of symbols. The trauma and conflicts created a "linear time framework" through events and the cyclical time of narratives and fragmented memories. The linear time relates to the representative history of events through the publicity and production of situations (media, political and social interests, experiences), and the cyclical time relates to interests and the desire to return to the scene of the event in the form of exclusive and interactive memories. The goal of the analysis is to confront linear and cyclical time in the (re)construction, interpretation and reactualization of mass events.
\end{abstract}

Keywords: public spaces, Belgrade, history, memory, narratives, symbolic.

\section{Analytical mobility}

The political and geostrategic divide between the countries of former Yugoslavia, nationalistic euphoria and economic crisis led to war, antagonisms, conflicts, existential poverty, refugee drama, and personal tragedies with the inevitable baggage of crime, destruction, and the rise of a pseudo-elite. Those were the years of a hyperactive reality, "social drama", a "risk society ${ }^{2 "}$ and uncertainty witnessed

1 This paper is a result of the work on the Project Cultural Heritage and Identity (177026), funded by the Ministry of Education, Science and Tehnological Development of the Republic of Serbia.

2 "Social drama" manifested itself in public episodes of tensional irruption (Turner 1974: 33). The transition from external to manufactured risk society and crisis of responsibility see: Giddens 1999: 8. 
through an eruptive tension of destabilizing processes. Not accidentally, the historical drive marked the events that became real and symbolic coordinates of change and the breaking points of European socialist countries (the geopolitical breakup of the Soviet Union 1985-1989, changes in Poland 1981-1989, Czechoslovakia 1989, Romania 1989, Bulgaria 1989, and the fall of the Berlin wall in 1989). Tensions in the countries of Eastern Europe began with conflicts between the political factions of ruling parties, the rise of populist movements, civil disobedience, and resistance, which marked a sociopolitical movement in the struggle for territory, power, rights, and freedoms. The rush and the collapse of the political scenes completely changed private and public life. Politics stepped out into the streets, so that it could be said that the 1980s and 1990s reanimated open urban spaces as arenas for the vox populi. In some eastern European countries, the streets were a place of protest against Soviet-style communist regimes, and in the Western Balkans, the streets became a mass national outcry for secessionism, territorial sovereignty, and civil rights, against violence and war. Mass and public action established a new configuration of political supremacy and subordination on a daily basis. Choosing for or against such conditions in our century became just as serious as choosing for or against nuclear weapons (Moskovisi 1997: 346).

The masses in the streets were no longer a concept of the mob (Le Bon, Tarde, Freud), but focused mobilized people with certain requests, needs, interests, and aspirations. These are precisely the metropolises as symbols of a whole and diverse population that have demonstrated, what Mumford calls the creation and differentiation of opportunities for ordinary life and the significant collective drama between disintegration and the need for reintegration (2010: 545). However, all that remains behind us and with us, creating new understandings through (re) construction, interpretation, and the re-actualizations of history and memory. For Katherine Verderi, all those events of the late $20^{\text {th }}$ century, which were foreseen neither by politicians nor by experts, later gave cause for many analyses, as scientists with hindsight began to understand what they had not been able to understand before (2005: 40). From that perspective, the phenomena of the politicization and socialization of street events are never at rest, but with time are re-actualized, as independent memory units and united documentaries. Through the reception of individual memories and collective experiences, events are either "avoided or exchanged", so they are reconstructed in media forms and ritual reenactment (Asman 2011: 13). Everything mentioned falls into the traumatic Yugoslav experience or the cascade of events which will be discussed in this paper.

The beginning of the Yugoslav crisis moved people to gather on the streets and squares. By the end of the 1980s mass gatherings polarized political scenes and arenas by form, content, and goals, establishing the public speech of the street as a declarative instrument of citizen determination and proclamation. This period of public exaltations created communicative events which later became interpretative and (re)constructed events/discourses. The situational activism included 
interpretative mobility as a particular form of communication, which took place simultaneously as the events (first of all in the press, in columns, reports, news, speeches, and slogans). For such a galloping daily life, the scientific and research discourse was left stunned by the speed and level of event frequency, and was always unprepared to deal with it critically. In the social and historical sciences and the humanities, encouraged by a turbulent public scene, the analytical discourse was met with the primary option of how to defend national identity with regard to a fatherland, ${ }^{3}$ as opposed to the discourse which from the beginning took a critical stance toward the role of the national in the process of democratization. My basic opinion is that mass events put in motion an avalanche of dissatisfaction against the regime, but most of all through the polarity of glorifying nationalism and opposing it. ${ }^{4}$ Publications from that time, in some way, reflected the discursive binarism which determined the phenomenon of mass gatherings as a national question and civil insurgency. So for example, during the 1990s, sociological publications and papers dealt exclusively with the topic of demonstrations, with a focus on student protests ${ }^{5}$ (Milić, Čičkarić 1998; Čupić 1998; DragičevićŠešić 1997). Ethnographic and anthropological research widened the analytical horizons to include the topics of political symbols: ethno mythology (ProšićDvornić 1993; Čolović 1997), forms of political holidays (Đorđević 1997), and self-reflective events (Gorunović, Erdei 1997). Those years completely destroyed the cliché of "research distance and objectivity", creating a new field of "double agent" in everyday life (Naumović 1998: 101-120). Science was left to solve the dilemmas and contradictions of the traumatic history of the Western Balkans, but also to raise the question or doubt when it came to the narrative's focus and memory. The analytical approach in this paper focuses on the chronological and symbolical field of (re)constructing the past - mass gatherings between 1988 and 2000 in Belgrade. The trauma and conflicts created a linear (chronological) time through events and cyclical time of narratives and fragmented memories. The linear time relates to the representative history of events through publicity and production of situations (media, political and social interests, experiences), and the cyclical time relates to interests and the desire to return to the scene of the event in the form of exclusive and interactive memories. The goal of the analysis is to confront the linear and the cyclical time in the (re)construction, interpretation and re-actualization of mass events. The anthropological narrative is constructed on recognizable markers originating from rich personal data (interviews, media

3 As Olivera Milosavljević states, great intellectual efforts were engaged in order to redfine nationalism as "good nationalism" (https://pescanik.net/dobri-nacionalizam/, 2007).

4 In intellectual circles the phrase "Second Serbia" was used, based on the book Second Serbia (ed. Čolović, Mimica 1992) where speeches and open discussions of those who were criticizing the war, authoritarianism and nationalism were published.

5 There have been over 50 papers written about anti-regime demonstrations, and especially student protests, mostly scientific articles, directly after the events (Tomić 2009: 184). 
narratives, photo documentation and videos) combined with all available web and printed sources. However, the focus in this paper is put on discursive location of meaning (of space, communication, behaviour, perception) in order to shed anew light on the mass gatherings in Belgrade, in particular regarding their complexity and asymmetry with the past.

\section{Multiple homogenization of history ${ }^{6}$ and the politics of symbols}

I problematize mass and public events in Belgrade through chronologies of these events, their contents, the types of meetings and the politics of symbols. The locations of public gatherings in Belgrade are the streets and squares in the city center: The Republic Square, Terazije, Nikola Pašić Square, King Milan’s Street to Slavija Square, King Aleksandar's Boulevard, Knez Miloš' Street, Takovska Street and Nemanjina Street. State buildings and national institutions are located in this zone (the Parliament, the Presidency building, the City Council, the National Theatre, the National Museum, the National Television building, the Ministry building, three Orthodox Christian churches (the Cathedral Church, St Mark's Church and the Church of the Ascension), the building of the Serbian Academy of Science and Art, faculties (the Technical Faculty, Faculty of Philosophy, Faculty of Philology and others) as well as monuments (the Monument to Knez Mihailo and the Terazije Fountain). ${ }^{7}$ The next zone of events are the green spaces in the suburbs (Ušće, Pionir Park, Tašmajdan). The third zone of events are sports halls and stadiums, open green spaces like the Košutnjak park, the Ušće plateau; lower Kalemegdan (the historical complex, fortress and park). All three zones are marked as historical markers of public events. Ceremonies, military parades, religious parades, celebrations (sport, music), meetings (regime), demonstrations, are all sorted into categories which I call spectacles of discipline, convention, emancipation and subversion. ${ }^{8}$ The diachronic level creates models which stem from historical markers as long - lasting and ephemeral events. These models can relate to previous political systems - ceremonies in honor of leaders (monarchism and

6 The term multiple "homogenization of history" is used to explain the way in which representative pasts has been shaped, constructed and harmonized by particular social and political groups. This term has been shaped thanks to the discussion with Lada Stevanović.

7 The center of Belgrade, especially the municipality Stari Grad, takes up about $7 \mathrm{~km}^{2}$ with a population of 55,543 (other municipalities are much larger and more populated). The city center, like most metropolises, is increasingly becoming a business area and an area for public events. However, the ratio of everyday life and events is still confronted between those who live and work in the Center and those attending an event.

8 In the analysis of socialist political and cultural spectacles, I created ideal-type models for the socialist period (Lukić Krstanović 2010: 259). 
socialism), and the celebration of ruling ideologies. On the other hand, protest models have their recognizable functions as a means of political struggle, the affirmation of collective and individual goals in risk zones, emancipation, destruction, subversion and regulation. Models are based on a trajectory of spatial models, and previous examples in pattern transfer. ${ }^{9}$

After the Second World War, mass spectacles took place according to clearly established scenarios in stadiums and on the boulevards (rallies, ${ }^{10}$ military parades and socialist rituals). They were devices of communist unity, cult and charisma. The streets were dedicated to festivities and socialist rituals in tick-tack time intervals. Rare dramatic moments (such as the student demonstrations of 1968) could disrupt the populist and popular comfort of Belgrade public scenes. And then came the dramatic 1990 s of the $20^{\text {th }}$ century.

In 1991 a territorial and nationalistic war began in Bosnia and Croatia, in which Serbian, Croatian and Bosnian military and paramilitary forces took part, which resulted in the dissolution of the Socialist Federal Republic of Yugoslavia. Slobodan Milošević and his socialist party came to power in 1990. The public scenes completely changed their physiognomy and function. Populism found cracks in nationalism, and civil disobedience and discontent rose to the surface, changing the borders of stable routines of public life toward dramatic turbulence. The first dramatic tide of masses began around the end of the 1980s. Public gatherings of citizens became a political tool for promoting the regime and national aspirations. This type of mass gathering changed the scenography into iconography. The stage design for meetings became a job of creating scenic cultivation (leader cult, nation cult) and "war propaganda folklore", creating the illusion that the individual interests of warmongers are actually those of the people and the nation's interest (Čolović 1994: 9). The complete meeting repertoire was directed to that patriotic and war opus of guarding Serbian borders and the Serbian people in Croatia, Bosnia and in Kosovo. The creation of the leader and party oligarchy got its full expression through populist meetings organized by the government. Those mass gatherings of support for the ruling politics and the Serbian nation were called "happenings of the people". ${ }^{11}$ The agitation and scenario of the meet-

9 Chroniclers, interpreters and witnesses of public gatherings usually establish certain analogies: meetings of support for the regime of Slobodan Milošević in the 1990s are compared with socialist festivities dedicated to the socialist party and Josip Broz Tito (in the sphere of idolatry and leader cult). The student demonstrations of 1992 and 1996 were based on 1968. and the first public revolt for rights and freedoms. The stereotipization of role models has in time proven ineffective, because each period had its own causes and contents.

10 During the life of president of Yugoslavia, Josip Broz Tito, a spectacle was organized in Belgrade every year to celebrate his birthday on 25. May. This holiday has been called the Day of Youth since 1957.

11 Mass meetings in 1987 and 1988 in Belgrade were organized by the ruling party in order to support the Serbs and Montenegrins living in Kosovo with expressive messages against the "separatism of Kosovo Albanians". These mass gatherings (in front of the Federal Parliament and Ušće in 
ings were a synchronized trajectory of potential participants called mitingaši. The meetings of support for the regime were directed and regulated situations of amassing spaces for the needs of an autocratic state policy. They were publically advertised events promoted in the media with precisely indicated ritual coordinates: place of gathering, time of arrival, organized participation in the meetings (transportation by bus from companies and other parts of Serbia), a determined program which included an iconography, slogans and banners (such as, images of the president, slogans "Serbia, Serbia", the Serbian flag, music from the Serbian military past). Every following meeting was a copy of the previous one, which positioned uniformity at a level of unity and totality. There were direct broadcasts on state television for those meetings. In time, a group of mitingaši was formed - of activists controlled by the political oligarchy, who are always ready to show up and create a mass of defenders of the regime. That was how the network of populism spread to all major cities in Serbia, centered on Belgrade.

The next turning point in amassing the streets of Belgrade came from civil discontent and disobedience. Instead of a regime-created populist slogan "the people happened", the counter-slogan was "the disobedient citizen happened". During the protest, the citizens of Belgrade achieved the right to their city, the central core, both both symbolically and in reality (Vujović 2000: 132, 137). In the early 1990s, mass gatherings in the street were a political tool in the anti-regime struggle, the promotion of new leadership, civil organization and spontaneous initiatives with dramatic results. Those were the demonstrations of 1991, when the citizens demanded a change in the management of state television when strong police forces were engaged for the first time. In 1992 the opposition united under the name DEPOS, organizing several-week-long meetings titled "Vidovdan Convocation". Not only anti-regime citizens but also supporters of strong nationalistic politics took part in these protests, which would later prove to be the main trigger of national criminalization and militaristic tendencies. In 1996/97, during three winter months, the citizens of Belgrade and other cities in Serbia would gather every day on squares and organize mass protest walks against election thefts. Students played a great part in these events, gathering at certain checkpoints and protesting day and night in front of strong police cordons. The protest ended with the intervention of the OSCE and the passing of a law - the Lex specialis - by which the regime acknowledged the victory of the opposition on the local level of government (first of all in Belgrade). No matter how much the slogans of spontaneous citizen gatherings were favored, in a formal sense the protests were organized (by organization boards, leaders, monitors, and press services), but in illegal working conditions, and the media which supported the opposition was especially

New Belgrade) were an introduction to the central event organized in 1989. godine at Gazimestan in Kosovu, on the $600^{\text {th }}$ anniversary of the Battle for Kosovo, a complete political mythologization of this historical event and ethnic revival (Prelić 1995: 191). 
blocked. ${ }^{12}$ It is precisely in the sense of the media and the events taking place in the streets, that a social communitas ${ }^{13}$ was established. The leaders and the citizens became the main heroes of traumatic events and important actors of the protest history in the making.

Simultaneously with the regime and anti-regime meetings, there were gatherings of citizens who openly expressed their anti-war opinions. Peace organizations and actions came into existence spontaneously, as reactions to the war, the victims of war in Croatia and Bosnia, against all kinds of dictatorships and nationalism in countries of former Yugoslavia. In 1992, music bands such as Ekatarina Velika, Partibjekers and Električni Orgazam gathered around an anti-war project Rimitutituki, and recorded a song titled Slušaj vamo (Listen $U p$ ), which was played at a concert in the Republic Square in Belgrade. The same year, as part of the student demonstrations in the center of Belgrade, a truck with rock musicians, singing and calling out anti-war and anti-regime slogans, circled the protest. Even though the open spaces of the city were the main locations for the waves of dissatisfaction, there were permanent gatherings within the intellectual circles (the Belgrade Circle - sessions at the Youth Center (Dom Omladine) and at the Center for Cultural Decontamination) as a kind of engaged revolt. ${ }^{14}$ Among the most active anti-war organizations were the Women in Black (with their international and regional network), formed in 1991. This organization represented nonviolent resistance against militarism, war, sexism, nationalism, patriarchy, and fascism. Lighting candles to all the victims of war, rows of people wearing black armbands, open concerts, carrying slogans are just some of the activities/performances of citizens. Even though they were not huge, these meetings in Belgrade had some echo in the Region and among the citizens, but they were also risk zones of prohibited meetings which the regime severely condemned. ${ }^{15}$ Since 1998 , the more that the dictatorship became pronounced and the more that regime repressions took place, the more citizens took part in everyday protests. A movement named Otpor ${ }^{16}$ was established, whose actions involved a risky zone of activity (preven-

12 Especially radio B92 (since 1989), and press: "Naša Borba", "Vreme”, "Republika", "Demokratija" etc.

${ }^{13}$ I use social communitas in Turner meaning as idiosyncratic, spontaneity and freedom individuals (Turner 1974: 49).

14 The Center for Cultural Decontamination (Centar za kulturnu dekontaminaciju) was established in 1995, becoming a core of intellectual gathering in connecting poetics and politics, as a place of cultural and political dialogue, a public space for critique and affirmation.

15 The Women in Black organized protest actions in the streets and squares in Belgrade, which had different political-activist, moral, emotional, aesthetic-activist phases, levels and dimensions (www.zeneucrnom.org).

16 The people's movement Otpor was one of the phenomena which marked the political scene in Serbia since 1998. As a practical political organization and idea, Otpor demonized its political opponents, unerstandably refraining from pointig out the resposnsibility of citizens that needed to be won over for change (Ilić 2001: 1, 42). 
tion and arrests). The conflicts in the streets between the supporters of the regime and the civil opposition became more prominent. ${ }^{17}$

The situation in the public sphere of mass activity was made even more complicated by NATO intervention, and the bombing of targeted military and state objects in Belgrade in 1999. The manipulation by the regime (especially by the television) with patriotic and anti-American sentiments among the citizens, sparked mass gatherings of the citizens at Belgrade squares and bridges (concerts). The media manipulation and patriotic propaganda were aimed at amassing the streets of Belgrade, in order to express "spite" and "preserve the bridges and the squares with a living shield against the aggressors". After 1999, Belgrade once again stood out in a photo that circled the world. The date was October $5^{\text {th }} 2000$, when irregular presidential elections took place, and when for the last time the people demanded the resignation of the current president, his party, and oligarchy. A mass of people filled the streets, bringing about the fall of the regime of Slobodan Milošević and his party. This date marks the turning point and a symbolic break before and after October $5^{\text {th }}$ 2000. During the 1990s, the configuration of Belgrade public spaces was supported by cultural, religious and sports celebrations. During these ceremonies and festivities, cultural nationalism served as a suitable screen for the government at the time. As Đorđević wrote, football represents a highly competitive activity in which it is very important to win, which is the same system of values that nationalism rests on (2015: 31). The re-traditionalization of religious celebrations on the streets of Belgrade (religious parades during the Slava Spaso$v d a n$, for example $)^{18}$ fit into the national state programs, showing that in periods of crisis religion, culture and sport serve as instruments of ideology and politics.

The above-mentioned mass events in Belgrade established a controversial everyday life, which entirely changed the profile of public spaces in Belgrade. That is why I will sort these events based on a situational symbolism, which played a significant role in shaping the social spaces, and public and private life. Speaking about meetings, protests, sports celebrations, and concerts, means including the symbolic context of reading into the messages as relevant meanings of political and social expressions through the ritualization and creating spectacles of events. It is known that gatherings of people possess all the important characteristics of ritual experiences: expected behavior, highly stylized form, and repetitiveness. Public gatherings are usually ritualized in zones of transition from every day to the eventful life. When one becomes a participant in a parade, meeting, protest or concert, it includes a separation from everyday activities and roles, and an entering into a zone of happening - events that establish new relations - to be a participant at the head of a line, to carry props or banners, to be in the first rows (such as a fan

17 In 1996 and in 2000 in the very center of Belgrade, a simoultaneous gathering of pro and anti-regime citizens took place with a large number of police forces present.

${ }_{18}$ The slava of Belgrade - Spasovdan - re-established in 1993, after the end of socialism and the fall of Yugoslavia, as a large public ceremony, a church procession through the capitol. 
at concerts), to be endangered, apprehended or arrested (as in protests). All this shows how an everyday zone is abandoned for a zone of unordinary protocols and dramas. However, the public spaces in Belgrade during the 1990s established a social configuration of event repetition and fragmented perceptions. "Something is happening as usual", "Going to the usual meeting place again", "Chaos in the city again as usual" all the way to "The usual crowd and mob". The social and temporal code of events was perceived through everyday time, which established an effect of apparent lasting and physical engagement. The specific spaces established polarized social actions as a form of event-speech and spatial nomenclature. What did the spatial speech offer? Political orientations were expressed through communication, or rather through the polarization of conflict zones: supporters of the government called the protestors "hooligans and vandals", and the protestors called the regime structures "the red mob", the nationalists called the anti-war protestors "traitors". Every symbolic labeling spurred on the drama which was obviously being stored in long-term hatred and denial. Let's take a look at how the bearers of symbols as policy systems ${ }^{19}$ transformed in the event space. During the demonstrations of 1991, organized by the opposition against the government, the state television was called "The Bastille" as an infamous institution, or the Takovska Street was called "Tank Street", Kolarčeva Street - "Cordon Street", and the Republic Square was renamed "Freedom Square". The power of the masses and the power of buildings had certain compliance or rejection at times of events taking place. The National Theatre, a cultural symbol of the state, became a place from which the leaders of the opposition, standing on the balconies, spoke to the masses during the forbidden demonstrations of 1991 . At theatre plays, during the turbulent years, the actors would wear $\mathrm{t}$-shirts with the word otpor (resistance) as a sign of support for the opposition and the students. That kind of conversion of order into disobedience raised the public space - the buildings and the participants - to a higher level of symbolism and "social drama" ${ }^{20}$ On the other hand, the streets and the squares became a stage for sovereign dominance of canonized national symbols. The following example is about this: the symbolic break from socialism happened in 1997 when the socialist party lost the local elections for the first time. With the presence and ovations of a huge number of citizens, the red star was removed from the dome of the City Assembly building and a two-headed eagle was placed instead (the Serbian heraldic symbol of the monarchy). Changing spatial history is becoming a part

19 Presenting the bearers of political symbols and their orientation, from official functions to particular systems and groups (Azaryahu 1999: 258).

20 About the "inside" and "outside" of a theatre as important public spaces for communication and semantic messages, see the article by Sztandara (Sztandara 2018). In which the author wrote about two contradictory scenes, the play by Oliver Frljić about women victims of war at the National theatre in Rijeka, and at the same time the nationalistic celebration of Oluja in the city streets (Sztandara 2018). 
of a polisystem ${ }^{21}$ of breakup and seeming historical continuity (returning to the monarchist heritage) conceived through the mystification of "peoples" celebrations and new political (national) oligarchy. The showdown with the entire socialist heritage went hand in and with new/old street and square names (For example, Boulevard of (the) Revolution became the Boulevard of King Aleksandar, whilst Marshall Tito's Street became King Milan's Street. ${ }^{22}$ So, the canonized national symbols found a base in all forms of populism, promoting the nation and its mimicry - the people. That is why we can talk about the stereotyping of symbols which have relied on outdated and unskillful compilations of the national past (Đorđević 1998: 26). The national euphoria and imagination in the city center was taken up with all the war and tragic events of the Western Balkans and became a privileged part of city iconography. During the 1990s the city center was covered with visual and sonic symbols that established a holism of Serb-dom: at the central zone of Knez Mihailova Street one could hear musicians playing gusle with a newly composed repertoire about war heroes, there were Serbia-themed badges, šajkača hats, paintings of incriminated war leaders, leaflets with invitations to defend the fatherland, and illustrations of the Serbian past (Battle of Kosovo). The central zone of the city established a connection between mythological constellations and political everyday life, proving spatial supremacy in relation to other parts of the city. ${ }^{23}$

Celebrations themselves carry with them a desired offence and rebellion through the symbolism of practices; however, violence and crime are expressed through the destruction of symbols with a political goal of demolition. The most obvious example of the national criminalization of political actions happened in 2008 when a meeting was held against Kosovo's declaration of independence. Public figures held a series of fiery speeches against Kosovo's independence and for the preservation of the Serbian nation in Kosovo, followed by a march of several thousand people, and then an attack by militant groups on anything that alluded to anti-Serbian elements. Everything that was considered an anathema at the time was being destroyed: the buildings of the American and Croatian embassies and the flags were burned, the embassy of Turkey was stoned, and a McDonald's was

${ }^{21}$ I am using the formulation by Azaryahu, stating that political symbols are parts of different compositons of polisystems wich cross, overlap, and apply mutually competitively different options, but seem like a structural whole (Azaryahu 1999).

22 About corrections and name changes of Belgrade streets as instruments for achieving the goals of the ruling nomenclature see: Radović 2014: 135.

23 Raoul Girardet writes: "An experience shows that every one of those mythological 'constellations' can show up at the mutually most far apart points of a political horizon, that it can be determined both as a 'rightist' and a 'leftists', based on the moment and circumstances" (Žirarde/Girardet 2000: 20). The myth and nation became an umbrella sign manipulated by both the socialist party of Slobodan Milošević, the Yugoslav Leftist Party (lead by the wife of S. Milošević, Mirjana Marković), the radical rightist party of Vojislav Šešelj, and the monarchistic Serbian resistance movement of Vuk Drašković among others. 
demolished. City buildings, state symbols, consumer spaces became convenient tools for destructive confrontations between "ours" and "theirs/foreign/unfriendly", everything for national hegemony as a guarantee of state stability. Through the frequent expression of nationalist symbols based on triumph, trauma, and shame, a polarization was created with a "myth-motoric" ${ }^{4}$ developing between the two poles, convenient for every kind of hegemony. In such a formulation it is challenging to find space for blame.

Contrary to canonized symbols, the main representatives of favoring and glorifying the nation-state through all kinds of populism, emancipatory symbols were also at play as an expression of civil activism. That is neither populism, nor is it an expression of "the will of the people", nor the apotheosis of a leader, nor of the national past, but an individual expression of unity through messages and ideas that during the 1990s fell under the categories of: anti-war, solidarity with victims, civil rights, and opposition to dictatorship and autocracy. The student protests placed symbols outside of traditional clichés, creating an aura of humor and cynicism as thinking up and rationalizing political reality. Slogans and props were growing in numbers - like symbols of recognition and grouping: "Belgrade is the world", props with the Otpor logo, "Noise is in fashion", whistles, trumpets, stickers, badges with slogans "just passing through, I walk to annoy, fight cordons with cordons" and many other actions which established a spatial hegemony of physical unity. A special symbolic map of the city was created, which had its own checkpoints and coordinates through a situational intimization of "walking". This type of spatial emancipation in the city center determined rebellious freedom of movement, and as such definitely opened new horizons for street freedoms. Simultaneously with the street poetics of dissent came the rhetorical hegemony of leadership which was expressed in daily protest speeches by the leaders of the protests. The creative contents of the protest, especially humor, unlike meetings organized by the government, became known among the intellectual public as the "carnivalization of the city" and "para-theatre" (Jovičević 2000: 148), "ludism and festivity" (Đorđević, 1998: 30), and "holiday for democracy". However, every further bruegelism ${ }^{25}$ can blur real dramatic urges of events, which certainly had political motives and expressed strong civil discontent. The emancipated situational symbols and their bearers did not just include the masses, but also the strength of the message: black like sadness and death, standing in silence as a symbol of dignity and unacceptance, the body represents freedom and conscience; candles are for the victims of war, and flowers are for peace. Physical dynamism and inventiveness were the primary weapons of the resistance. It became apparent that the canonized symbols were a directed tool in raising national

24 I used formulas by Gincel (triumph and trauma) and Asmanova (triumph and the same), which best describe the mythomania of heroism (Asman 2011: 78).

25 Reference to the famous painting by Pieter Bruegel, The Fight Between Carnival and Lent, which is often referenced by analysts of festivities. 
morale and patriotism, which suited the hypertrophy of spatial centrism. Emancipated symbols, however, remained deeply embedded in interactive, interpersonal empathy (they existed in the center, but also in every other pocket of the city, from balconies to street corners).

A reflection of ideological and cultural antagonisms and animosities, exemplified by Belgrade, is expressed through the spatial symbolism of polarities: nationalist and cosmopolitan, traditional (patriarchal) and liberal, urban and folklore - creating special meta-constructs of divided groups and masses through: behavior, sound/noise, slogans, jargon, image, physicality and dynamism. In that duality of choices, they had no other option but to be against, with a lesser option for. ${ }^{26}$ All the faces of Belgrade street dramas hyper-produced and collected all the contradictions which made up the political and daily life scenes at the time. Eventful daily life through media production possessed certain elements of spectacles, through the visual centralization and spatial gigantism of a metropolis. ${ }^{27}$ The situational canonized and emancipated symbolism of public spaces in Belgrade of that time had its impact in: 1. inter and intragroup homogenization; 2. polarized differentiation, contrasts, and comparisons; 3 . recognizable distance; 4. encouraging affectivity; 5 . unhindered creativity (ideas and messages through humor). The politics of symbols are an essential instrument in (re)constructing the past of Belgrade's public spaces, creating multiple homogenization of history (consensual histories) that are considered essential for certain formations, groups, strategies, ideas; or, more precisely, for a privileged historical positioning within current politics. Is the problematization still directed at the exclusiveness of memories and interactive zones of individual memories?

\section{Exclusive and interactive memory}

The ephemerality of mass events in Belgrade is exhausted, but their cyclical persistence through post-narrative experiences and memories is not. Public gatherings are ranked and hold a high place on the scale of memories. The memory entities are made up of collections and constructions of memories that are gathered into

26 Perhaps the most eloquent statement by Čolović to the question "What is waiting for us after these protests?" - the end of the carnival is coming, the end of general solidarity [...], I can hardly wait for the moment when I won't have to tolerate every fool just because they are against Milošević, like I had to these past few weeks (1997: 290). The metaphore of the opposition - together and everyone, everyone, everyone was canonized in the official names of political coalitions "For changes - together", which was at the time composed of opposition parties of monarchist, democratic and civil orientation.

${ }^{27}$ Although metropolises write representative histories in eventful situations, other cities have a certain historical place as well. Cities that were bearers of political turmoil in Serbia at the time were: Novi Sad and Niš. 
recognizable sequences as special totalities of memory events. The narrative time and space construct social time, opening a complex network of activity - roles, relationships, retrospectives and rehearsing future pasts. It is clear that memories come from communication and interaction, but, to confirm an already known opinion - there is no collective memory, but we can talk about preparing for its "social imaginary" role. ${ }^{28}$ While I placed situational experiences and symbolic strategies in a linear time of stringing events together, further in the text I focus on cyclical time in the field of narration - witnessing (statements as a confirmation or negation of the past), memory (shaping knowledge and emotions from the past), remembering (data storage). Cyclical time included a period of constructing events through exclusive - representative memory (such as anniversaries, memories, analytic studies, or life histories) and a biased and desired returning to personal pasts. That is why I distinguish indicators that place Belgrade public events into narrative exclusive and private daily lives.

The exclusive memory includes the canonization of events in the field of representative history, "institutional memory" (Radović 2013: 31), which is "bureaucratized and politically instrumentalized" (Kuljić 2006: 36). With the coming of the opposition to power, all those who participated in the changes and achieved the respect of the main protagonists of the events took part in choosing their selected memories. However, the representative history includes those who maintained the position of power, especially in circles which support them, through the spectacularization of judicial processes, arrests, or meetings of support. ${ }^{29}$ For one side, the exclusiveness of memory is a confirmation of victory toward social change, and for others, it is a confirmation of justifications for the acts for which they were defeated and convicted. A privileged position of memory is instrumentalized with the help of power holders and institutions of power. Changes in the leadership mostly from the circles of opposition at the beginning of the $21^{\text {st }}$ century always carried with them benchmarks from the past. There is a lot of turmoil going on in the field of memory, because the contractual pasts of all participants have shown how different they are, and as time went on, they became increasingly more separated through confrontations and exaltation. Since 2000, when representatives of the opposition came to power, a schism started to take place between them. Conflicts regarding power carried with them a questioning of the past as a measure of historical status: where they were, what they were doing, how they behaved, and

28 Asman refers to Jacques Lacan and Benedict Anderson et al. who show a lack of trust in the concept of "collective memory" (Asman 2011: 30-31), collective memory as an assembly of reference points from everyday life which form collective social frameworks (Bojm 2005: 103). Jan Asman talks about collective memory, but through processes of socialization (Asman 2011: 34).

${ }_{29}$ Here I am mainly referring to the trials of Slobodan Milošević, Radovan Karadžić and Ratko Mladić at The Hague Tribunal and the great reactions that they had in the public (media), but also maintaining public gatherings of support for them. It is not a coincidence that thanks to representative symbols (the wearing of T-shirts with their image on various occasions) such as cultural and sports manifestations where their images and actions have remained contemporary. 
how they contributed? Politicians especially stood out, as did members of the media, artists, and academics. That cyclical time of (re)questioning the past through the manufacture of a memory of public gatherings, their organization, leaders, and supporters was a useful tool for mending current political everyday life. The reconstruction of events does not include just their chronological timeline, but also the schedule in which those who ordered these histories created representative entities of memory based on an agreement. A homogenization of memory remains on the level of collective constructs which came from clear event polarizations (regime meetings, civil and student protests, anti-war gatherings). That is why exclusive memories are directed by identifying patterns of recognizable markers. After the fall of Slobodan Milošević, no one spoke or wrote about the meetings organized by his party, let alone whether or not they were artistically inspired. Contrary to that, civil and student protests became strong residues of evocation, as time niches of renewed testimony and proof of the role and mission of their protagonists. With the help of evocators, these events are becoming instruments or confirmations of achieved successes called "democratic changes" or doubts about the effectiveness of those changes. ${ }^{30}$ Those kinds of entities of memory remain as separate wholes of public activity, useful for the production of parallel representative histories. Statements from testimonies and memories are based on the comparison of success in taking down a regime from the 1990s, and the relationship towards the current government. A great fiasco for the democratic and liberal sides after the presidential elections in 2017, when Aleksandar Vučić (Serbian Progressive Party) ${ }^{31}$ became president, carried with it the fabrication of a better rebellious past, as a good example of previous oppositional actions. In that case, the memories are treated as an instrument of the stimulus for putting such actions into motion. Witnesses - exclusive protagonists are retouching the past of the great public events of the 1990s through the totality of collective action and achieving goals in the fight for taking down regimes: "we have learned that a good organization of collective actions and the mobilization of citizens have a chance to change the regime". ${ }^{32}$ On the other hand, memories are a variable that can change, that enable maneuvering toward changing opinions and status. Some statements are such that democratic changes and student rebellion are easily converted as a national supplement: "the longest student rebellion in the history of the Serbian people or the Balkans" or "the national student movement". ${ }^{33}$ These and similar statements

30 Twenty years of civil and student protests: students seriously shook the regime of Slobodan Milošević. Their memories from those days, by Vuk Drašković, Vesna Pešić, Zoran Živković, Čedomir Antić et. al. Danas https://www.danas.rs/drustvo/studenti-su-ozbiljno-uzdrmali-rezimslobodana-milosevica/ (access: 12.07.2018).

31 A former leader of the rightist Serbian Radical Party.

32 Vesna Pešić, one of the leaders of the protest in the interview: https://www.danas.rs/drustvo/ studenti-su-ozbiljno-uzdrmali-rezim-slobodana-milosevica/ (access: 12.07.2018).

33 Interview with Čedomir Antic: https://www.danas.rs/drustvo/studenti-su-ozbiljno-uzdrmali-rezim-slobodana-milosevica/ (access: 12.07.2018). 
are classified through the standpoint of memory as identities, for the purpose of constructing national histories. Various exhibitions, plays, literary works, films and anniversaries contribute to the circulation of the culture of memory through chosen projects and interpretations. The moment when they become a question of state-building, memories become loyal to the establishment, losing all freedom of evocation beyond the border. One example of this is the way in which Serbia took part in the Prague Quadrennial with the project "Theatre - Politics - City" in 2007, inspired by Belgrade as a synonym for a public political stage. Through the culture of memory, public non-institutional scenes are being institutionalized through memory; they become historical representatives with the utilitarian interests of the bearers of those memories. ${ }^{34}$ Exclusive memories are spectacular memories because they require an audience. They have no return effect. VIP narratives are one-way and require their own recipients - in other words, like-minded individuals. Exclusive memories fight for the hegemony of positioning in the histories of Belgrade street dramas.

Interactive memories - my story, our story, and the general story are not always compatible. It has been shown that the history of public gatherings in Belgrade has its stereotypical and clichéd trajectories as representative histories (the multiple homogenization of history) of the city, state, nation or government, followed by exclusive shaped memories loyal to the responsible past, and finally, individual memories, fragmented memories through episodic collections of memories. ${ }^{35}$ Life experiences are turned into stories of the actors of the events: participants, observers, non-participants, organizers, and individuals from the structures of public safety and the police forces, speakers, attackers, victims, co-contributors and those who were convicted. Such an experienced reality was everything for one side, nothing for another, and something for a third. The constructs of individual personal histories took place through social interactions and communication between the I - we group. What are the narrative systems that determine the dramatic character of private memories in the zones of interactions?

34 A similar example happened on the occasion of the fifth anniversary of the Student protests 1968-2018, and an exhibition at the Serbian Academy of Science and Art, with the goal of breaking the barrier of conservative and nationalistic institutions. This example shows that memory (re) constructions can be moved, suppressed, renewed and mixed up with representative scenes of evocation.

35 During 1992-1993, and later 1996, and 1997, 1999 I collected material about current mass events on the streets of Belgrade. A large number of statements that I gathered along the way I turned into street narratives as a text. Returning to everyday life post festum gives new experiences and interpretative contents - participants become heroes of stories and transmitters of stories (Lukić Krstanović 1995: 223-224). After more than 20 years I renewed my conversations with about a dozen protagonists of events. The distance of 20 and more years showed that interpretative time connects to memories of experiences, which creates its own symbolic coordinates of selective impressions and data. 
Individual memory within a collective past is symbolically limited in the construction of a collective understanding of before which is separate from the present "by the force of a radical break" (Jansen 2005, 13). Mass gatherings on the streets of Belgrade were divided into a time before and after, which was also achieved by a generational plebiscite by which the transition - or break, becomes a substitute for an eventful daily life. As an example I offer episodic sequences of three interviewees - three generations:

The earliest that I can remember masses on the streets of Belgrade is March 27 ${ }^{\text {th }} 1941$, and my mother making a flag out of cloth and waving it for the protestors in Karađorđe's Park; I remember the parade for May $1^{\text {st }}$, in which I participated, and the line of people next to the stands in front of the Parliament, and then come the 90s, something completely different. I first went to meetings organized by the government (Ušće), it was organized for us to go from work. And then something in me changed. I support the protests of the opposition. I took coffee with my granddaughter to the students at Kolarčeva and had political disputes with my husband (woman, 84 years).

Yes, I also remember the parades, we were privileged because we lived in Dragoslav Jovanovićs Street and we could watch the parade from the window. Then the 90s came - I lived on the street, I worked on the street and slept on the street (woman, 60 years).

A lot of empathy, hatred, exaltation - a lot of things in common, and a lot of personal things. I was a kid, and I remember telling my parents "there is some kind of chaos on the streets again", and then I got a bit older, and banged pots and pans with my parents, and blew whistles. Near the end of the 90s I distributed fliers for Otpor and classes were always canceled, so it was great (woman, 33 years).

This generational habitus marks the polyvalence of perceptions through living - memories contained in the phrase "I changed". Spatial memory is based on experience and knowledge, and temporal memory comes from the ability to preserve and pass them on (between individuals and groups). That is why agreement (history and memory) is more important for spatial symbolism, and negotiations (what to remember and pass on) are more important for temporal symbolism. The socio-political break has caused socio-psychological phases of rites of passage (just like the rituals of the life cycles of birth and death). Here events on the streets of Belgrade awaken certain sentiments which stem from extended impressions through participation and orientation. However, wider versions, individual life stories include a context in which the protagonists - heroes of the stories position themselves into certain identifying collectives and political aspirations with the possibility of changing political options. So political and/or life trajectories become confronted in the deconstruction of living memories.

Individual memory remembers confrontations, conflicts, and breakups and skillfully combines them into their own dramatic niches. The majority of memories from the 1990s contain traumatic everyday life on the street. From contradictory points of view, it looks like this: 
I knew everything that was going on, and in my family, I supported the government; to people who shared my opinions, I would say that it's just a bunch of hooligans on the streets destroying the city. My family wasn't supportive of my views. I went to a meeting organized by the government once, and my daughter was on the opposing side, it was a horrible family fight (man, 85 years).

I worked for the police and protected the citizens from the non-citizens, I don't want to talk about it (man, 68 years).

I went to meetings in Belgrade with my organization to support the government, it was all right, but we would encounter provocations from the opposition along the way (woman from city Čačak, 65 years).

From the beginning I was a "walker", in that crowd there were all kinds of people and extreme nationalists whom I could not agree with; we would always blow our whistles together, scream and run into the hot zones of police cordons (woman, 51 years).

It was great during the state news on television when I would put speakers on the balcony and play Simply Red (woman, 53 years).

I got hit with batons and tear gas at the beginning of Knez Mihailova Street. I still remember the euphoria of the mass of people in one place, when I ran into a stampede and almost got run over (man, 49 years).

We came from Aranđelovac and set up tents at the Pionir Park with a sign "For the King and Fatherland" (man, 68 years).

Belgrade is a metropolis, which in many ways indicates centralization and supremacy in relation to all the places outside the "center". To be a protagonist of the Belgrade street scene meant to be "at the center of activities". However, the mass is an imaginary concept which serves many manipulations, as an instrument for every kind of manipulation from above. On the opposite end of the mass is the body - actions (I am walking, running, sleeping, fleeing, speaking, screaming, standing, being quiet), masked, painted, clothed (caps, painted tricolor, t-shirts with Serbian symbols or cosmopolitan symbols of peace and resistance). The greatest number of Belgrade memories are based on the physicality of events, which is perhaps the most distinctive and convincing way of announcing participation in an event. For the politics of the street, the rule always applies that all activism include bodies "between". The more the activism and intervention are inventive and dynamic, the more the messages are intense. In that sense, I can see a physical difference of bodies of discipline (regime meetings), bodies of emancipation (protests). Judith Butler writes in Bodies in Alliance and the politics of the Street::

This happens most clearly when we think about bodies that act together. No one body establishes the space of appearance, but this action, this perfomative exercise happens only "between" bodies, in space that constitutes the gap between my own body and another's. In this way, my body does not act alone, when it acts politically. Indeed, the action emerged from the "between" (Butler 2011). 
Memory is an image and a body. In 2018 the Women in Black (around thirty activists) used their bodies to write messages of memories of the victims of the mass killing of Bosniaks in 1995 in Srebrenica. It all takes place at the Republic Square, where once one could hear strong calls to war. Outside of exclusiveness, massiveness, event ephemerality, and what is covered by the nation-state, these and similar actions raise the event to an ethical level of responsibility for crimes with far-reaching reminders, often overlooked and repressed.

The narratives that represent the different memory worlds of Belgrade spaces are not exhausted this way. Memories and testimonies are the leading players in the representative proof of truths, but also in the realization of social interactions and empathies of collective and personal narrative experiences. My research has shown that memories have become so sensationalized, often nationally heroic, that there is little space left for remembering the other side of human life and suffering.

\section{The models and reflections: coming histories and memories}

Representative events are not neutral: they either camouflage everyday life or they carry it with them in order to change it. These are two opposing sides which will exist in these areas and times for a long time. So, the political is the living, and every context of public spaces is part of that package. Any other ethnological zoom cannot be freed from this real fact. It is possible to discuss further to what extent the perceptive percentage in historical evocational (re)construction kinesthetic and sensory is. Multiple homogenization of history and evocation certainly do not agree with self-reflection of experiences, because that is how any possibility of paradigmaticity and modulations is destroyed. On the other hand, what will we do with life stories, memories, and their storage? Who are they left for and who will find them important? Public testimonies and private memories cannot achieve a consensus of credibility. This can be seen in the judicial processes of Balkan events, where testimonies and experiences often part, following certain interests in proving the truth. The truth exists, it just needs to be placed in the correct spot. Historical practices and archival production contribute to the shaping of political subjects and actors of public events. 


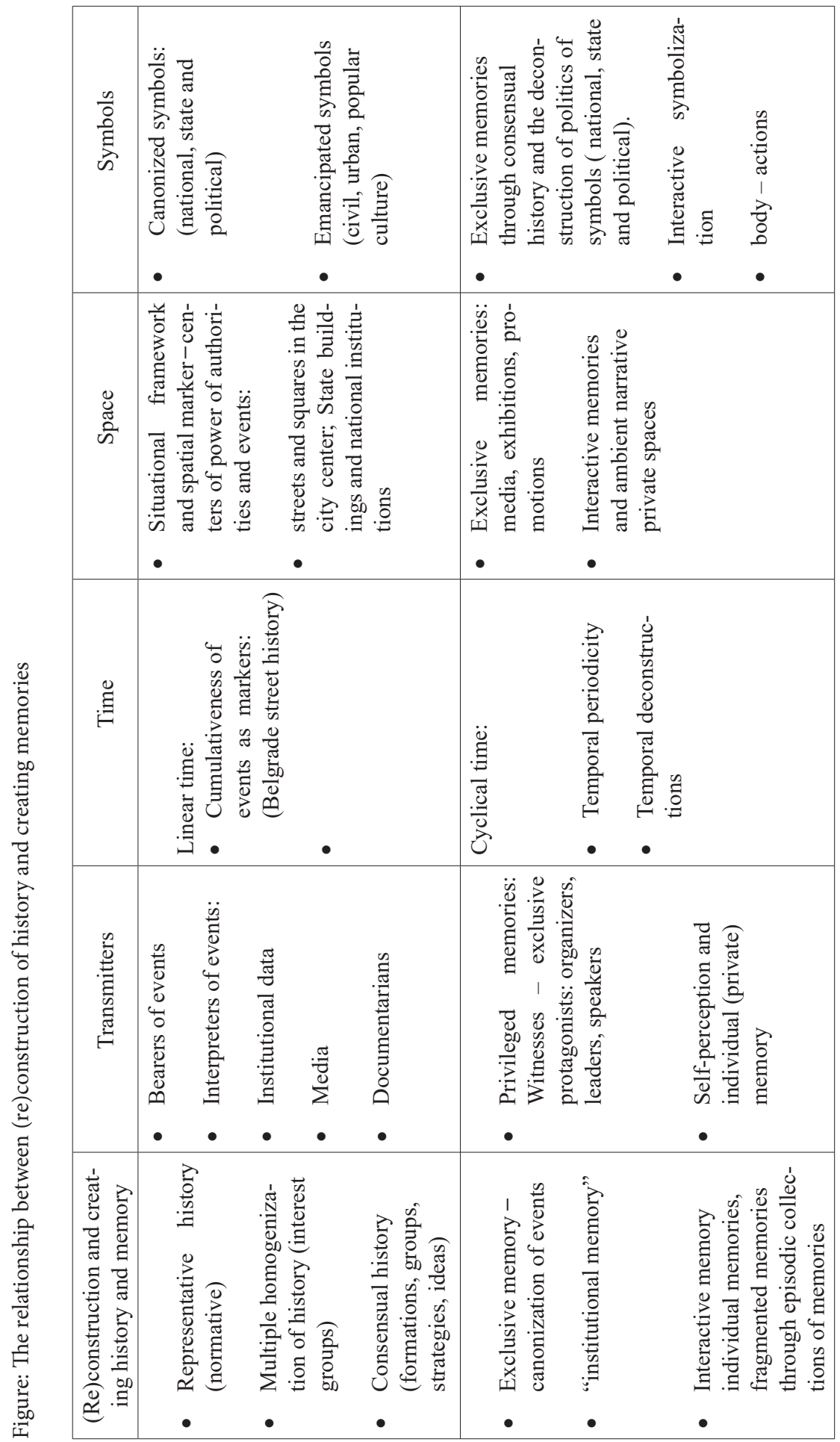


Descriptive, explanatory and interpretive zooming in on public events in Belgrade indicates a certain social movement as networks. ${ }^{36}$ "Remembering from a distance" relies on memory as a reservoir of data, whereas experienced impressions are molded into a sentiment of spatial memory. The projection of reconstructing in the present renews the memories by embodying them in a space. In the spring of 2017 civil protests took place in front of the City Hall because of the demolition of a part of Sava Mala (gentrification). Magdalena Sztandara conducted field exercises with her students from Krakow, as part of these events (2017, 485-490). I held a short lecture for the students about the history of public events in Belgrade. That was my comeback to the experienced past as a double insider - a participant and a researcher. This linear cyclicity of spatial time fits into the flow of the (re)construction of the past and re-actualization of events. If I come back to the spatial civil discipline and symbolic canonization, on the one hand, as opposed to the emancipated "disobedient" civil activism through interactive symbolization, the history of Belgrade public spaces has sown a greater attachment to discipline and single-mindedness. The 1990s made a significant step toward the emancipation of public activism, but not enough to place society on a sufficient level of critical engagement and the permanent mobility of keeping society vigilant. Protests, strikes, and sabotage are types of social movement that have been treated more as historical events with their protagonists, and less as an active public everyday life with engaged actors here and now.

\section{Bibliography}

Azaryahu M.

1999 Politički simboli u svakidašnjici: polisistemski pristup istraživanju, Etnološka "tribina”, no 22/29, 255-267.

Asman A.

2011 Duga senka prošlosti / Der Lange Schatten der vergangnheit, Beograd. Bojm S.

2005 Budućnost nostalgije / The Future of Nostalgia, Beograd.

Butler J.

2011 Bodies in Alliance and the Politics of the Street,-http://eipcp.net/transversal/1011/ butler/en, (access: 16.07.2018).

Čolović I.

1994 Pucanje od zdravlja / Shooting of Health, Beograd.

1997 Politika simbola, Ogledi o političkoj antropologiji, Beograd.

36 The social movement are not organisations, like political parties or interests gropus, but rather are networks, composed of diverse range of interconnected and interacting individuals, gropus and organisations (Gibb 2001: 2). 
Čolović I., Mimica A. (ed.)

1992 Druga Srbija, Beograd.

Čupić Č.

1998 Duh vedrine, Kultura protesta - protest kulture, Građanski i studentski protest 96/97, Beograd.

Dragićević-Šešić $M$.

1992 Druga Srbija, in: I. Čolović, A. Mimica (eds.), Beogradski krug, Centar za antiratnu akciju, Beograd.

1997 Ulica kao politički prostor. Prostor karnevalizacije, "Sociologija” no 39(1), p. 5565.

Đorđević I.

2015 Antropolog među navijačima / An anthropologist among fans, Beograd.

Đorđević J.

1998 Simbolika protesta, in: Duh vedrine, kultura protesta, ed. Č. Čupić, Beograd, p. 21-32.

Gibb R.

2001 Toward and Anthropology of Social Movements, "Journal des anthropologues", no 8586, http://journals.openedition.org/jda/2904 (access: 23 April 2018).

Giddens A.

1999 Risk and Responsibility, “The Moder Law Review”, vol. 62, no. 1, p. 1-10, https://courses.washington.edu/sales09/Handouts/Giddens_Risk_Responsibility.pdf (access: 24.04. 2018).

Gorunović G., Erdei. I.

1997 O studentima i drugim demonima, Zbornik radova studenatat etnologije $i$ antropologije Filozofskog fakulteta u Beogradu, Beograd.

Ilić V.

2001 Između Evrope i retradicionalizacije - Narodni pokret “Otpor”, vol. 1, Helsinški odbor za ljudska prava u Srbiji, Beograd.

Jansen S.

2005 Antinacionalizam, Beograd.

Jovičević A.

2000 Teatar, parateatar i karneval: Građanski i studentski protesti u Srbiji 1996-1997, in: Urbani spektakli, ed. M. Dragičević-Šešić, Beograd, p. 147-160.

Kuljić T.

2006 Kultura sjećanja, Beograd

Lukić Krstanović M.

1995 Masovna politička okupljanja. Priče iz života, "Glasnik Etnografskogo institute SANU" no XLIV, p. 222-234.

2010 Spektakli XX veka. Muzika i moć, Beograd.

Milić A., Čičkarić L.

1998 Generacija u protesta, Sociološki portret učesnika Studentskogo protesta 96/97 na Beogradskom univerzitetu, Beograd.

Milosavljević O.

2007 "Dobri" nacionalizam, https://pescanik.net/dobri-nacionalizam/ (access: 6.07.2018).

Moskovisi S.

1997 Doba gomile / L'age des Foules, Beograd. 
Mumford L.

2010 Kultura gradova, Novi Sad.

Naumović S.

1998 Romanticists or Double Insiders? An Essay on the Origins of Ideologised Discourses in Balkan Ethnology, "Ethnologia Balkanica", no. 2, p. 101-120.

Prelić M.

1995 Revival of the Serbian National Myth (The Myth of the Battle of Kosovo) in the Contemporary Public Speech in Serbia, "Etnologia Balkanica”, p. 191-206.

Prošić-Dvornić M.

1993 "Enough" - Student Protest '92. The Youth of Belgrade in Quest of "Another Serbia", "Anthropology of East Europe Review", no 11 (1-2), p. 129-130.

Radović S.

2014 Beogradski Odonimi/Belgrade Odonyms, Beograd.

Sztandara M.

2017 Sporna susedstva i praksa vraćanja grada natrag svojim stanovnicima: slučaj kvarta Savamala u Beogradu, "Glasnik Etnografskogo instituta SANU”, no LXV (2), p. 485-490.

2018 To be Unworthy of National Stage. Women's Disobedience as Performative Practices, "Glasnik Etnografskogo instituta SANU" no 2, p. 347-366.

Tomić Đ.

2009 Ulične studije - Odsek Protesti! Studentski protesti tokom" ere Milošević”, in: Novi društveni pokreti u Jugoslaviji od 1968 do danas, (eds.) Đ. Tomić, P. Atanacković, Novi Sad, p. 184-231.

Turner V.

1974 Dramas, Fields and Metaphors, Symbolic Action in Human Society, London.

Verderi K.

2005 Šta je bio socijalizam i šta dolazi posle njega / What was Socialism and What Comes Next?, Beograd.

Vujović S.

2000 Beograd kao pokretni praznik, in: Urbani spektakl, ed. M. Dragičević-Šešić, I. Šentevska, Beograd, p. 130-146.

Žirarde R.

2000 Politički mitovi i mitologije, Beograd.

Press data

Danas, https://www.danas.rs/drustvo/studenti-su-ozbiljno-uzdrmali-rezim-slobodana-milosevica/ (access: 12.07.2018).

www.kaleidoskop-media.com/klik-na-svetlost/prote (access: 6. 07. 2018). 